\title{
KINERJA SEKOLAH DIPREDIKSI DARI BIAYA PENDIDIKAN, KEPEMIMPINAN KEPALA SEKOLAH, PERAN KOMITE SEKOLAH, DAN IKLIM SEKOLAH
}

\author{
Afifah Nur Amaliah, Kardoyo, Jarot Tri Bowo Santoso
}

Jurusan Pendidikan Ekonomi, Fakultas Ekonomi, Universitas Negeri Semarang, Indonesia

\section{Info Artikel}

Sejarah Artikel:

Diterima, 3 Januari 2020

Disetujui, 10 Maret 2020

Dipublikasikan, 30 Juni

2020

\section{Keywords:}

Cost of Education,

Principal Leadership,

Role of School

Committee, School

Climate, Quality of

Process and Quality of

Graduates

\begin{abstract}
Abstrak
Tujuan penelitian ini adalah untuk menganalisis pengaruh langsung biaya pendidikan, kepemimpinan kepala sekolah, peran komite sekolah, dan iklim sekolah secara parsial terhadap mutu lulusan, dan pengaruh tidak langsung melalui mutu proses. Penelitian ini menggunakan pendekatan kuantitatif ex-post facto dengan sampel 28 SMA Negeri yang dipilih menggunakan menggunakan teknik cluster sampling. Metode pengumpulan data menggunakan metode dokumentasi dan angket. Metode analisis data menggunakan analisis deskriptif, analisis jalur dan uji sobel. Hasil penelitian menunjukkan bahwa (1) Secara parsial biaya pendidikan, iklim sekolah, peran komite sekolah, dan mutu proses berpengaruh secara positif dan signifikan terhadap mutu lulusan. (2) Kepemimpinan kepala sekolah tidak berpengaruh secara signifikan terhadap mutu lulusan. (3) Biaya pendidikan dan iklim sekolah berpengaruh secara positif dan signifikan terhadap mutu proses. (4) Mutu proses dapat memediasi biaya pendidikan dan iklim sekolah terhadap mutu lulusan secara parsial, dan tidak dapat memediasi kepemimpinan kepala sekolah dan peran komite sekolah terhadap mutu lulusan. Kesimpulan dalam penelitian menunjukan bahwa mutu proses hanya berperan sebagai mediator pada biaya pendidikan dan iklim sekolah.
\end{abstract}

\begin{abstract}
The purpose of this study is to analyze the influence of the direct effect of education costs, principal leadership, role of school committees and school climate partially on the quality of graduates, and indirect influence through the quality process. The approach used quantitative ex-post facto. The sample that taken as much as 28 school by cluster sampling technique. Data collection method used documentation and questionnaire method. Researcher used descriptive analysis, path analysis, and sobel test as the method to analyze the data.The results showed that (1) partially the cost of education, school climate, the role of the school committee, and the quality of the process had a positive and significant effect on the quality of graduates. (2) Principal leadership does not significantly influence the quality of graduates. (3) Partially the cost of education and the school climate have a positive and significant effect on the quality of the process. (4) The quality of the process can mediate the cost of education and school climate on the quality of graduates partially, and cannot mediate the leadership of the principal and the role of the school committee on the quality of graduates. Based on the results of the above studies, it can be concluded that the quality of the process only acts as a mediator in the costs of education and school climate.
\end{abstract}

Alamat korespondensi:

Gedung L2 Lantai 1 FEUnnes

Kampus Sekaran, Gunungpati, Semarang, 50229

E-mail: afifah_alkhanza@yahoo.com 


\section{PENDAHULUAN}

Indonesia merupakan negara berkembang yang telah jauh mempersiapkan pendidikan yang berkualitas sejak kemerdekaan Indonesia. Hal itu dibuktikan dengan Pembukaan Undang-undang Dasar 1945 yang berbunyi “...melindungi segenap bangsa Indonesia dan seluruh tumpah darah Indonesia dan untuk memajukan kesejahteraan umum, mencerdaskan kehidupan bangsa, dan ikut melaksanakan ketertiban dunia yang berdasarkan kemerdekaan, perdamaian abadi dan keadilan sosial...."

Dalam Pembukaan UUD 1945 tersebut mengandung makna bahwa, Indonesia harus mampu menjamin pemerataan kesempatan pendidikan, peningkatan mutu serta relevansi dan efisiensi manajemen pendidikan untuk menghadapi tantangan sesuai dengan tuntutan perubahan kehidupan lokal, nasional, dan global sehingga perlu dilakukan pembaharuan pendidikan secara terencana, terarah, dan berkesinambungan (UU No 20 Tahun 2003). Namun dalam prakteknya, Indonesia masih belum optimal dalam mewujudkan pendidikan nasional yang berkualitas. $\mathrm{Hal}$ tersebut dirasakan masih banyaknya masalah-masalah yang menghampiri pendidikan di Indonesia. Data Kementerian Pendidikan dan Kebudayaan hasil Ujian Nasional menurun dalam kurun waktu tiga tahun belakangan sejak tahun 2015 sampai dengan 2017, yang terlihat sebagai berikut.

Tabel 1. Hasil Rata-Rata UN Tingkat Nasional

\begin{tabular}{cc}
\hline Tahun & Rata-Rata UN \\
\hline $\mathbf{2 0 1 7}$ & 48,02 \\
$\mathbf{2 0 1 6}$ & 54,78 \\
$\mathbf{2 0 1 5}$ & 61,29 \\
\hline
\end{tabular}

Sumber: puspendik.kemdikbud.go.id 2018, diolah

Jawa Tengah yang merupakan salah satu provinsi di Indonesia turut serta dalam menyumbang kondisi pendidikan nasional yang berkualitas. Namun jika dilihat dalam prakteknya, kondisi pendidikan di Jawa Tengah masih dalam kondisi memprihatinkan yaitu dibawah rata-rata tingkat nasional. Hal ini cukup terlihat dari rata-rata masyarakat di provinsi Jawa Tengah dalam mengenyam pendidikan baru hampir delapan tahun, dan lebih dari $60 \%$ tenaga kerja di Jawa Tengah saat ini masih lulusan Sekolah Dasar atau SD (https://iatengprov.go.id/publik).

Sekolah yang merupakan pelaksana sistem pendidikan menjadi aktor utama yang menentukan kualitas pendidikan. Terlebih dengan adanya Sistem Manajemen Berbasis Sekolah (MBS), sekolah diberikan otonomi dalam mengelola sesuai dengan standar mutu pendidikan yang ditetapkan pemerintah. Dalam pelaksanaan sistem pendidikan menuntut adanya perubahan dalam sistem supervisi di sekolah dalam hal ini supervisi akademik, supervisi administrasi maupun supervisi lembaga yang bukan hanya sebagai alat pengawasan tetapi juga pembinaan terhadap penyelenggara pendidikan. Pengawasan dan pembinan tersebut harus dapat berjalan seimbang agar dapat dicapai kinerja yang optimal.

Proses perbaikan terhadap seluruh aspek pendidikan ditujukan untuk terselenggaranya layanan pendidikan yang berkualitas, sehingga dapat menghasilkan lulusan pendidikan yang sesuai dengan standar yang ditetapkan. Kondisi di lapangan menunjukkan bahwa masih terdapat sekolah yang belum memenuhi standar yang baik yang terlihat dari masih banyaknya sekolah yang belum mendapat akreditasi, data tersebut diantaranya sebagai berikut.

Jawa Tengah terbagi menjadi enam karesidenan salah satu diantaranya adalah karesidenan Semarang. Karesidenan Semarang terdiri dari beberapa kota/kabupaten di provinsi Jawa Tengah dan menjadi bagian yang tidak dapat terlepaskan dalam mewarnai kondisi pendidikan Jawa Tengah dan Nasional. Bagian dari karesidenan Semarang diantaranya Kota Semarang, Kabupaten Semarang, dan Kota Salatiga. Meskipun dalam pertumbuhan pendidikan di Kota Semarang khususnya, telah banyak lembaga pendidikan yang berdiri baik formal maupun non formal, dirasakan masih kurang dalam berkontribusi memperbaiki 
masalah pendidikan yang ada baik tingkat provinsi maupun nasional. Kabupaten Semarang dan Kota Salatiga merupakan kota/kabupaten yang lokasinya lebih dekat dengan Kota Semarang.

Hasil Ujian Nasional yang dapat menggambarkan mutu lulusan yang dihasilkan sekolah pada beberapa tahun belakangan menunjukkan hasil yang juga belum memuaskan dan cenderung turun di Kota Semarang, Kabupaten Semarang, dan Kota Salatiga.

Tabel 2. Rata-Rata UN SMA Negeri di Kota Semarang, Kabupaten Semarang, dan Kota Salatiga Tahun 2015 - 2017

\begin{tabular}{llll}
\hline Kota/Kabupaten & $\mathbf{2 0 1 7}$ & $\mathbf{2 0 1 6}$ & $\mathbf{2 0 1 5}$ \\
\hline Kota Semarang & 56.69 & 55.34 & 59.96 \\
Kab Semarang & 53.91 & 55.33 & 56.14 \\
Kota Salatiga & 61.67 & 58.01 & 62.26 \\
\hline
\end{tabular}

Sumber: Puspendik Kemendikbud 2017, diolah

Sekolah sebagai lembaga pendidikan yang menjadi tempat berlangsungnya proses pendidikan, mempunyai sistem yang dinamis dan kompleks. Kegiatan sekolah bukan hanya sebagai tempat berkumpulnya murid dengan guru, akan tetapi sekolah adalah sebuah sistem yang kompleks dan saling berhubungan yang akan berpengaruh terhadap kinerja sekolah. Kinerja sekolah disini maksudnya ialah mutu lulusan yang dilihat melalui mutu proses. Faktor - faktor apa saja yang mempengaruhi kinerja sekolah bisa dilihat dari faktor input atau masukan yang dimiliki oleh sekolah diantaranya seperti biaya pendidikan, kepemimpinan kepala sekolah, peran komite sekolah, dan iklim sekolah.

Biaya pendidikan, termasuk dari mana sumber-sumbernya diperoleh, sangat berpengaruh terhadap proses pendidikan. Sumber biaya pendidikan berasal dari Anggaran Pendapatan dan Belanja Negara (APBN), Anggaran Pendapatan dan Belanja Daerah (APBD), masyarakat atau orang tua siswa, dan pihak lain yang berhubungan dengan pendidikan (Mulyono, 2010).

Sejak tahun 2008 anggaran pendidikan dalam APBN sudah mencapai $20 \%$. Hal ini sesuai amanat UU No 20 Tahun 2003 tentang Sistem Pendidikan Nasional pasal 49 ayat 1 mengatur bahwa dana pendidikan selain gaji pendidikan dan biaya pendidikan kedinasan, minimal wajib dialokasikan sebesar $20 \%$ dari APBN dan APBD. Namun kenyataannya anggaran tersebut belum dialokasikan secara efektif.

Anggaran pendidikan dari pusat sebagian besar digunakan untuk keperluan gaji guru yang secara kinerja guru yang dihasilkan pun masih belum sesuai harapan, dan kelengkapan sarana prasarana yang masih memerlukan banyak pembenahan (Triyono, 2016). Anggaran dari daerah untuk kebutuhan pendidikan masih banyak yang belum memenuhi peraturan yaitu $20 \%$, seperti yang terjadi di Kota Semarang, Kabupaten Semarang, dan Kota Salatiga pada tahun 2015.

Menurut Fattah (2001) pemerintah memang memiliki keterbatasan dalam hal ketersediaan dana dan daya untuk membiayai pendidikan, dan ini menuntut manajer pendidikan dalam hal ini kepala sekolah untuk mengelola secara efisien dan efektif. Kepala sekolah merupakan orang yang memiliki kekuasaan dan pengaruh dalam menentukan kondisi di sekolah, kehidupan sekolah diatur sedemikian rupa oleh kepemimpinan kepala sekolah (Kompri, 2015). Sesuai Permendiknas No. 28 Tahun 2010 tentang Penugasan Guru sebagai Kepala Sekolah, siapapun yang diangkat sebagai kepala sekolah ditentukan melalui prosedur dan syarat tertentu diantaranya: latar belakang pendidikan, pengalaman, usia, pangkat dan integritas.

Dalam menjalankan tugas kepala sekolah dituntut memiliki lima kompetensi diantaranya kompetensi kepribadian, manajerial, supervisi, sosial, dan kewirausahaan. Dari kelima kompetensi tersebut, tugas utama yang harus dijalankan kepala sekolah ialah tugas manajerial, pengembangan kewirausahaan, dan supervisi guru dan tenaga kependidikan, sesuai dalam Peraturan Pemerintah No 19 Tahun 2017. Hasil Ujian Kompetensi Sekolah yang dikeluarkan Kemendikbud nilai kompetensi kepala sekolah 
dalam rata-rata nasional adalah 41,49 dan itu tergolong rendah (Fadillah, 2015).

Peran komite sekolah yang menjadi perwakilan dari masyarakat juga menjadi faktor yang tak terlepaskan dalam mempengaruhi kinerja sekolah. Kementerian Pendidikan dan Kebudayaan telah merevitalisasi ulang fungsi dan peran komite sekolah melalui Permendikbud Nomor 75 Tahun 2016, komite sekolah tidak hanya bertugas menggalang dana dari orang tua murid saja melainkan dapat meningkatkan pelayanan pendidikan dengan prinsip gotong royong, jelas, transparan dan akuntabel.

Kenyataan di lapangan, bahwa komite sekolah yang terdiri dari guru dan bukan orang tua murid di sekolah tersebut belum berperan optimal. Suroto (2017) menyebut saat ini lebih dari 50\% komite sekolah di Indonesia tidak sesuai dengan ketentuan regulasi yang diatur dalam Permendikbud No. 75 Tahun 2016 dan cenderung sebagai pengumpul dana. Mayoritas masalah yang dihadapi oleh komite sekolah adalah minimnya kapasitas untuk mengelola dan menjalankan organisasi.

Iklim sekolah merupakan kondisi atau suasana sekolah yang dapat menentukan gambaran tentang kinerja sekolah. Hapsari (2014) menyebutkan bahwa fenomena di dunia pendidikan yang muncul saat ini adalah banyaknya siswa yang tidak disiplin dalam belajar, misalnya sering datang terlambat ke sekolah, membolos, mengumpulkan tugas tidak tepat waktu, tidak mengerjakan pekerjaan rumah, tidak mengikuti upacara bendera, dan lebih mengkhawatirkan lagi adalah berkelahi dengan teman yang terutama sering dilakukan oleh siswa.

Sehubungan dengan hal tersebut yang telah dijelaskan di atas, perlu dilihat bagaimana pengaruh biaya pendidikan, kepemimpinan kepala sekolah, peran komite sekolah, dan iklim sekolah terhadap kinerja sekolah. Sehingga perlu dilakukan penelitian lebih lanjut terkait kondisi kinerja sekolah, penelitian ini akan berfokus pada lokasi di Kota Semarang, Kabupaten Semarang, dan Kota Salatiga yang merupakan bagian dari eks-Semarang, Jawa Tengah.

Tujuan penelitian ini diantaranya: (1) Menganalisis pengaruh biaya pendidikan, kepemimpinan kepala sekolah, komite sekolah, iklim sekolah, mutu proses secara parsial terhadap mutu lulusan pada SMA Negeri di Kota Semarang, Kabupaten Semarang, dan Kota Salatiga, (2) Menganalisis pengaruh biaya pendidikan terhadap mutu lulusan melalui mutu proses pada SMA Negeri di Kota Semarang, Kabupaten Semarang, dan Kota Salatiga, (3) Menganalisis pengaruh kepemimpinan kepala sekolah terhadap mutu lulusan melalui mutu proses pada SMA Negeri di Kota Semarang, Kabupaten Semarang, dan Kota Salatiga, (4) Menganalisis pengaruh peran komite sekolah terhadap mutu lulusan melalui mutu proses pada SMA Negeri di Kota Semarang, Kabupaten Semarang, dan Kota Salatiga, (5) Menganalisis pengaruh iklim sekolah terhadap mutu lulusan melalui mutu proses pada SMA Negeri di Kota Semarang, Kabupaten Semarang, dan Kota Salatiga.

\section{METODE}

Jenis penelitian ini menggunakan jenis kuantitatif. Desain penelitian yang digunakan dalam penelitian ini adalah ex-post facto. Populasi yaitu SMA Negeri yang terdiri dari seluruh SMA Negeri di Kota Semarang, Kabupaten Semarang, dan Kota Salatiga sejumlah 30 SMA Negeri dan diperoleh sampel sebesar 28 SMA Negeri.

Metode pengumpulan data menggunakan metode dokumentasi dan angket. Metode analisis data menggunakan analisis deskriptif dan analisis inferensial yaitu analisis jalur, uji hipotesis dan uji sobel.

\section{HASIL DAN PEMBAHASAN}

Penelitian ini dilakukan di SMA Negeri se-Kota Semarang, Kabupaten Semarang, dan Kota Salatiga pada tahun ajaran 2017/2018 dengan sampel penelitian 28 SMA Negeri. Sekolah yang dijadikan sampel terdiri dari 15 SMA Negeri di Kota Semarang, 10 SMA Negeri di Kabupaten Semarang, dan 3 SMA Negeri di Kota Salatiga. 


\section{Deskriptif Variabel Biaya Pendidikan}

Data pada variabel biaya pendidikan diperoleh melalui pedoman dokumentasi berupa hasil pengeluaran yang dilakukan oleh sekolah dengan mengacu pada RKAS (Rencana Kerja Anggaran Sekolah) pada tiap-tiap SMA Negeri di Kota Semarang, Kabupaten Semarang, dan Kota Salatiga. Hasil analisis deskriptif statistik dengan bantuan SPSS dapat diperoleh hasil sebagai berikut:

Tabel 3. Deskriptif persentase variabel Biaya Pendidikan

\begin{tabular}{clc}
\hline $\begin{array}{c}\text { Interval (jutaan } \\
\text { rupiah) }\end{array}$ & \multicolumn{1}{c}{ Kriteria } & $\%$ \\
\hline$>5.323-6.517$ & Sangat Baik & $14.29 \%$ \\
$>4.130-5.323$ & Baik & $10.71 \%$ \\
$>2.936-4.130$ & Cukup & $42.86 \%$ \\
$>1.743-2.936$ & Tidak baik & $21.43 \%$ \\
$549-1.743$ & $\begin{array}{l}\text { Sangat tidak } \\
\text { baik }\end{array}$ & $10.71 \%$ \\
\hline
\end{tabular}

Sumber: data penelitian diolah, 2018.

Berdasarkan tabel 3 perhitungan di atas menunjukkan hasil bahwa rata-rata keseluruhan variabel biaya pendidikan pada SMA Negeri di Kota Semarang, Kabupaten Semarang, dan Kota Salatiga berada pada kriteria cukup, dengan persentase $42,86 \%$. Kriteria sangat baik sebanyak 4 SMA Negeri dengan persentase $14.29 \%$. Kriteria baik sebanyak 3 SMA Negeri dengan persentase $10.71 \%$. Kriteria cukup sebanyak 12 SMA Negeri dengan persentase $42.86 \%$. Kriteria tidak baik sebanyak 6 SMA Negeri dengan persentase $21.43 \%$. Kriteria sangat tidak baik sebanyak 3 SMA Negeri dengan persentase $10.71 \%$.

\section{Deskriptif Variabel Kepemimpinan Kepala Sekolah}

Data penelitian pada variabel kepemimpinan kepala sekolah diperoleh melalui angket atau kuesioner, hasil yang diperoleh pada variabel kepemimpinan kepala sekolah adalah sebagai berikut:

Tabel 4. Deskriptif persentase variabel Kepemimpinan Kepala Sekolah

Interval Kriteria Frekuensi Persentase

\begin{tabular}{cccc}
\hline $\mathbf{4 . 5 0 - 4 . 6 2}$ & Sangat Baik & 2 & $7.14 \%$ \\
$\mathbf{4 . 3 7 - 4 . 4 9}$ & Baik & 9 & $32.14 \%$ \\
$\mathbf{4 . 2 4 - \mathbf { 4 . 3 6 }}$ & Cukup & 6 & $21.43 \%$ \\
$\mathbf{4 . 1 1 - 4 . 2 3}$ & Tidak baik & 3 & $10.71 \%$ \\
$\mathbf{3 . 9 8 - 4 . 1 0}$ & $\begin{array}{c}\text { Sangat } \\
\text { tidak baik }\end{array}$ & 8 & $28.57 \%$ \\
\hline
\end{tabular}

Sumber: Data Penelitian diolah, 2018

Berdasarkan perhitungan rata-rata pada tabel 4 terlihat bahwa variabel kepemimpinan kepala sekolah pada SMA Negeri di Kota Semarang, Kabupaten Semarang, dan Kota Salatiga dalam kriteria baik, dengan persentase $32,14 \%$. Kriteria sangat baik sebanyak 2 SMA Negeri dengan persentase $7,14 \%$. Kriteria cukup sebanyak 6 SMA Negeri dengan persentase $21,43 \%$. Kriteria tidak baik sebanyak 3 SMA Negeri dengan persentase $10,71 \%$. Kriteria sangat tidak baik sebanyak 8 SMA Negeri dengan persentase $28,57 \%$.

\section{Deskriptif Peran Komite Sekolah}

Data penelitian pada variabel peran komite sekolah diperoleh melalui angket atau kuesioner, hasil yang diperoleh pada variabel peran komite sekolah adalah sebagai berikut:

Tabel 5. Deskriptif persentase variabel Peran Komite Sekolah

\begin{tabular}{cccc}
\hline Intreval & Kriteria & Frekuensi & Persentase \\
\hline $3.65-3.95$ & Sangat Baik & 1 & $3.57 \%$ \\
$3.35-3.64$ & Baik & 9 & $32.14 \%$ \\
$3.04-3.34$ & Cukup & 15 & $53.57 \%$ \\
$2.74-3.03$ & Tidak baik & 1 & $3.57 \%$ \\
$2.43-2.73$ & $\begin{array}{c}\text { Sangat tidak } \\
\text { baik }\end{array}$ & 2 & $7.14 \%$ \\
\hline
\end{tabular}

Sumber: Data Penelitian diolah, 2018

Berdasarkan perhitungan rata-rata pada tabel 5 terlihat bahwa variabel peran komite sekolah pada SMA Negeri di Kota Semarang, Kabupaten Semarang, dan Kota Salatiga dalam kriteria cukup, dengan persentase 53,57\% dengan frekuensi sebanyak 15 SMA Negeri. Kriteria sangat baik sebanyak 1 SMA Negeri dengan persentase $3.57 \%$. Kriteria baik sebanyak 9 SMA Negeri dengan persentase $32.14 \%$. Kriteria tidak baik sebanyak 1 SMA Negeri dengan persentase $3.57 \%$. Kriteria 
sangat tidak baik sebanyak 2 SMA Negeri dengan persentase $7.14 \%$.

\section{Deskriptif Iklim Sekolah}

Data penelitian pada variabel iklim sekolah diperoleh melalui angket atau kuesioner, hasil yang diperoleh pada variabel iklim sekolah adalah sebagai berikut:

Tabel 6. Deskriptif persentase variabel Iklim Sekolah

\begin{tabular}{cccc}
\hline Interval & Kriteria & Frekuensi & Persentase \\
\hline $4.20-4.31$ & Sangat Baik & 4 & $14.29 \%$ \\
$4.08-4.19$ & Baik & 7 & $25.00 \%$ \\
$3.95-4.07$ & Cukup & 6 & $21.43 \%$ \\
$3.83-3.94$ & Tidak baik & 7 & $25.00 \%$ \\
$3.71-3.82$ & Sangat tidak & 4 & $14.29 \%$ \\
& baik & & \\
\hline
\end{tabular}

Sumber: Data Penelitian diolah, 2018

Berdasarkan perhitungan rata-rata pada tabel 6 terlihat bahwa variabel iklim sekolah pada SMA Negeri di Kota Semarang, Kabupaten Semarang, dan Kota Salatiga dalam kriteria baik dan tidak baik, dengan persentase masing-masing 25\%, dengan frekuensi 7 SMA Negeri. Kriteria sangat baik, dengan persentase $14.29 \%$ dengan frekuensi sebanyak 4 SMA Negeri. Kriteria cukup sebanyak 6 SMA Negeri dengan persentase $21.43 \%$. Kriteria sangat tidak baik sebanyak 4 SMA Negeri dengan persentase $14,29 \%$.

Setelah diperoleh data tersebut, maka dapat dideskriptifkan pengeluaran tertinggi biaya pendidikan untuk Kota Semarang, Kabupaten Semarang, dan Kota Salatiga ialah pada SMA Negeri 1 Semarang dengan jumlah pengeluaran sebesar Rp6.517.160.000, dan pengeluaran biaya pendidikan terkecil di Kota Semarang, Kabupaten Semarang, dan Kota Salatiga ialah pada SMA Negeri 1 Susukan dengan jumlah pengeluaran sebesar Rp549.787.800.

\section{Persamaan Regresi}

Hasil analisis jalur melalui 2 tahap regresi yaitu pengaruh biaya pendidikan $\left(\mathrm{X}_{1}\right)$, kepemimpinan kepala sekolah $\left(\mathrm{X}_{2}\right)$, peran komite sekolah $\left(\mathrm{X}_{4}\right)$, dan mutu proses $\left(\mathrm{Y}_{1}\right)$ terhadap mutu lulusan $\left(\mathrm{Y}_{2}\right)$. Kemudian persamaan kedua yaitu pengaruh biaya pendidikan $\left(\mathrm{X}_{1}\right)$, kepemimpinan kepala sekolah $\left(\mathrm{X}_{2}\right)$, peran komite sekolah $\left(\mathrm{X}_{4}\right)$, dan mutu proses $\left(\mathrm{Y}_{2}\right)$. Seperti tergambar pada persamaan di bawah ini:

$$
\begin{aligned}
& \text { Persamaan } 1 \quad: Y_{2}=\rho_{1} \mathrm{X}_{1}+\rho_{2} \mathrm{X}_{2}+\rho_{3} \mathrm{X}_{3} \\
& +\rho_{4} \mathrm{X}_{4}+\rho_{5} \mathrm{Y}_{1}+\mathrm{e}_{1} \\
& \begin{array}{l}
\text { Persamaan } 2 \\
+\rho_{4} \mathrm{X}_{4}+\mathrm{e}_{2}
\end{array}
\end{aligned}
$$

Berdasarkan hasil analisis jalur yang didapat menghasilkan koefisien regresi dalam tabel 8 .

Tabel 7. Hasil Uji Regresi Linier Berganda dengan Mutu Lulusan Sebagai Variabel Dependen

\begin{tabular}{clllll}
\hline \multicolumn{7}{c}{ Coefficients $^{\mathbf{a}}$} \\
\cline { 1 - 4 } Model & \multicolumn{2}{c}{$\begin{array}{c}\text { Unstandardized } \\
\text { Coefficients }\end{array}$} & $\begin{array}{c}\text { Standardized } \\
\text { Coefficients }\end{array}$ & $\mathrm{t}$ & Sig. \\
& \multicolumn{2}{c}{$\mathrm{B}$} & Std. Error & Beta & \\
\cline { 2 - 4 } & -107.688 & 21.038 & & -5.119 & .000 \\
(Constant) & $1.193 \mathrm{E}-9$ & .000 & .216 & 2.223 & .037 \\
X1 & 2.275 & 4.176 & .052 & .545 & .591 \\
X3 & 10.634 & 2.398 & .433 & 4.434 & .000 \\
X4 & 14.045 & 4.030 & .317 & 3.486 & .002 \\
Y1 & 15.659 & 5.631 & .313 & 2.781 & .011 \\
\hline
\end{tabular}

Sumber: Data Penelitian diolah, 2018 


\section{Persamaan Regresi Pertama}

Persamaan regresi yang diperoleh berdasarkan tabel 8 tersebut adalah sebagai berikut:

$$
\begin{aligned}
\mathrm{Y}_{2}= & 0,216 \mathrm{X}_{1}+0,052 \mathrm{X}_{2}+0,433 \mathrm{X}_{3}+0,317 \mathrm{X}_{4} \\
& +0,313 \mathrm{Y} 1+\mathrm{e}_{1}
\end{aligned}
$$

Nilai e1 $=\sqrt{1-R^{2}}=\sqrt{1-0.863}=\sqrt{0.137}=$ 0,3701 .

Sehingga diperoleh persamaan regresi sebagai berikut:

$$
\begin{aligned}
Y_{2}= & 0,216 X_{1}+0,052 X_{2}+0,433 X_{3}+0,317 X_{4} \\
& +0,313 Y_{1}+0,370
\end{aligned}
$$

Persamaan regresi tersebut mempunyai makna sebagai berikut: (1) Koefisien Biaya Pendidikan $\mathrm{X}_{1}=0,216$, jika variabel Biaya Pendidikan mengalami kenaikan sebesar satu poin, maka mutu lulusan $Y_{2}$ naik sebesar 0,216. (2) Koefesien Kepemimpinan Kepala Sekolah $\mathrm{X}_{2}=$ 0,052, jika variabel Kepemimpinan Kepala Sekolah mengalami kenaikan sebesar satu poin, maka mutu lulusan $Y_{2}$ naik sebesar 0,052 . (3) Koefisien Peran Komite Sekolah $\mathrm{X}_{3}=0,433$, jika variabel Peran Komite Sekolah mengalami kenaikan sebesar satu poin, maka mutu lulusan $\mathrm{Y}_{2}$ naik sebesar 0,433 . (4) Koefisien Iklim Sekolah $\mathrm{X}_{4}=0,317$, jika variabel Iklim Sekolah mengalami kenaikan sebesar satu poin, maka mutu lulusan $\mathrm{Y}_{2}$ naik sebesar 0,317. (5) Koefisien Mutu Proses $Y_{1}=0,313$, jika variabel Mutu Proses mengalami kenaikan sebesar satu

\begin{tabular}{|c|c|c|c|c|c|}
\hline \multirow{2}{*}{ Model } & Unstandardized Coefficients & \multirow{2}{*}{$\begin{array}{c}\text { Standardized Coefficients } \\
\text { Beta }\end{array}$} & & \multirow{2}{*}{\multicolumn{2}{|c|}{ Sig. }} \\
\hline & Std. Error & & & & \\
\hline (Constant) & 1.769 & .686 & & 2.579 & .017 \\
\hline $\mathrm{X} 1$ & $4.058 \mathrm{E}-11$ & .000 & .368 & 2.257 & .034 \\
\hline $\mathrm{X} 2$ & .183 & .150 & .210 & 1.223 & .234 \\
\hline X3 & .072 & .088 & .147 & .827 & .417 \\
\hline $\mathrm{X} 4$ & .305 & .135 & .344 & 2.259 & .034 \\
\hline
\end{tabular}
poin, maka mutu lulusan $Y_{2}$ naik sebesar 0,313 .

Tabel 8. Hasil Uji Regresi Linier Berganda dengan Mutu Proses Sebagai Variabel Dependen

Coefficients $^{\mathrm{a}}$

Sumber: Olah Data Penelitian, 2018

\section{Persamaan Regresi Kedua}

Persamaan regresi yang diperoleh berdasarkan tabel tersebut adalah sebagai berikut:

$\mathrm{Y}_{1}=0,368 \mathrm{X}_{1}+0,210 \mathrm{X}_{2}+0,147 \mathrm{X}_{3}+0,344 \mathrm{X}_{4}+\mathrm{e}_{2}$

Nilai $e_{2}=\sqrt{ } 1-R^{2}=\sqrt{ } 1-0,508=\sqrt{ } 0,492=0,7014$

Sehingga diperoleh persamaan regresi sebagai berikut:

$$
\begin{aligned}
Y_{1}= & 0,368 X_{1}+0,210 X_{2}+0,147 X_{3}+0,344 X_{4} \\
& +0,701
\end{aligned}
$$

Persamaan regresi tersebut mempunyai makna sebagai berikut: (1) Koefisien Biaya Pendidikan $\mathrm{X}_{1}=0,368$, jika variabel Biaya Pendidikan mengalami kenaikan sebesar satu poin, maka mutu proses $Y_{1}$ naik sebesar 0,368 . (2) Koefisien Kepemimpinan Kepala Sekolah $\mathrm{X}_{2}=0,210$, jika variabel Kepemimpinan Kepala Sekolah mengalami kenaikan sebesar satu poin, maka mutu proses $Y_{1}$ naik sebesar 0,210 . (3) Koefisien Peran Komite Sekolah $X_{3}=0,147$, jika variabel Peran Komite Sekolah mengalami kenaikan sebesar satu poin, maka mutu proses $Y_{1}$ naik sebesar 0,147. (4) Koefisien Iklim Sekolah $\mathrm{X}_{4}=0,344$, jika variabel Iklim Sekolah mengalami kenaikan sebesar satu poin, maka mutu proses $Y_{1}$ naik sebesar 0,344 .

\section{Total Pengaruh}

Besarnya pengaruh langsung biaya pendidikan terhadap mutu lulusan sebesar 0,216 atau sebesar $21,6 \%$. Sedangkan besarnya pengaruh tidak langsung biaya pendidikan terhadap mutu lulusan melalui mutu proses sebagai variabel mediasi adalah sebesar $0,313 \times$ $0,368=0,115=11,5 \%$.

Besarnya pengaruh langsung kepemimpinan kepala sekolah terhadap mutu lulusan sebesar 0,526 atau sebesar 52,6\%. 
Sedangkan besarnya pengaruh tidak langsung kepemimpinan kepala sekolah terhadap mutu lulusan melalui mutu proses sebagai variabel mediasi adalah sebesar $0,313 \times 0,210=0,066=$ $6,6 \%$.

Besarnya pengaruh langsung peran komite sekolah terhadap mutu lulusan sebesar 0,433 atau sebesar 43,3\%. Sedangkan besarnya pengaruh tidak langsung kepemimpinan kepala sekolah terhadap mutu lulusan melalui mutu proses sebagai variabel mediasi adalah sebesar $0,313 \times 0,147=0,046=4,6 \%$.

Besarnya pengaruh langsung iklim sekolah terhadap mutu lulusan sebesar 0,344 atau sebesar 34,4\%. Sedangkan besarnya pengaruh tidak langsung kepemimpinan kepala sekolah terhadap mutu lulusan melalui mutu proses sebagai variabel mediasi adalah sebesar $0,313 \times 0,344=0,108=10,8 \%$. Dan besarnya pengaruh langsung mutu proses terhadap mutu lulusan adalah sebesar 0,313 atau 31,3\%.

Hasil uji penelitian yang telah diungkapkan di atas, memberikan makna bahwa model penelitian yang diajukan dapat diterima. Hasil pembahasan dalam penelitian ini dapat diungkapkan sebagai berikut:

\section{Pengaruh Biaya Pendidikan Terhadap Mutu Lulusan}

Biaya pendidikan merupakan komponen yang penting untuk menunjang berlangsungnya pelaksanaan pendidikan. Pengelolaan biaya pendidikan yang baik dapat memberi kualitas mutu yang baik pula bagi penyelenggara pendidikan. Pedoman dokumentasi yang digunakan dalam melihat biaya pendidikan yang dikeluarkan pada SMA Negeri di Kota Semarang, Kabupaten Semarang, dan Kota Salatiga, ialah dengan melihat pada komponen belanja pegawai, belanja barang dan jasa, dan belanja modal.

Berdasarkan hasil pengujian, diketahui biaya pendidikan berpengaruh secara positif dan signifikan terhadap mutu lulusan secara langsung sebesar $21.6 \%$, artinya peningkatan biaya pendidikan sebesar satu satuan akan diikuti oleh kenaikan mutu lulusan 21.6\% dengan catatan variabel kepemimpinan kepala sekolah, peran komite sekolah, iklim sekolah, dan mutu proses tetap. Hal ini sesuai dengan penelitian Alvionita \& Armas (2014) yang menyimpulkan bahwa biaya pendidikan berpengaruh dan signifikan terhadap mutu lulusan.

\section{Pengaruh Kepemimpinan Kepala Sekolah Terhadap Mutu Lulusan}

Kepemimpinan kepala sekolah yang terdiri dari beberapa indikator diantaranya pengelola program pengajaran, pengelola pelayanan tenaga kependidikan, pengelola pelayanan siswa, pengelola hubungan sekolah dan masyaraakat, dan pengelola keuangan dan fasilitas. Kepala sekolah sebagai pimpinan tertinggi dalam sekolah memiliki otoritas kebijakan untuk menentukan arah dan tujuan untuk tercapainya mutu lulusan yang baik. Dengan diberlakukan nya Manajemen Berbasis Sekolah (MBS) kepala sekolah diberi kepercayaan lebih dalam perencanaan, pengorganisian, pelaksanaan, dan evaluasi.

Berdasarkan hasil pengujian, diketahui bahwa kepemimpinan kepala sekolah tidak berpengaruh secara signifikan terhadap mutu lulusan sebesar pada SMA Negeri di Kota Semarang, Kabupaten Semarang, dan Kota Salatiga. Hal ini berbeda dengan penelitian terdahulu yang dilakukan Ningsih, dkk (2016), Awaludin (2017) yang menunjukkan adanya pengaruh signifikan kepemimpinan kepala sekolah terhadap mutu sekolah. Perbedaan hasil antara hasil yang dilakukan peneliti dengan penelitian terdahulu bisa disebabkan karena perbedaan objek penelitian,waktu penelitian, lokasi penelitian, dan pengaruh lain yang tidak diteliti dalam penelitian ini.

\section{Pengaruh Peran Komite Sekolah Terhadap Mutu Lulusan}

Peran komite sekolah dengan indikator yang disesuaikan dengan Permendikbud Nomor 75 Tahun 2016 yaitu memberikan pertimbangan kebijakan, penggalangan dana, pengawasan pelayanan, dan tindak lanjut keluhan, saran, kritik dan aspirasi. Keberadaan komite sekolah harus bertumpu pada landasan partisipasi masyarakat dalam meningkatkan 
kualitas pelayanan dan hasil pendidikan di sekolah.

Berdasarkan hasil pengujian yang dilakukan peneliti, peran komite sekolah berpengaruh secara positif dan signifikan terhadap mutu lulusan sebesar 43,3\%, artinya setiap kenaikan satu satuan peran komite sekolah akan meningkatkan mutu lulusan sebesar 43,3\% dengan ketentuan variabel lain dalam penelitian ini tetap. Hal ini sesuai dengan penelitian Solihin (2017) bahwa kinerja komite sekolah berkontribusi terhadap Mutu Sekolah, oleh karena itu tinggi rendahnya mutu sekolah didukung/disumbang pula oleh kinerja komite sekolah.

\section{Pengaruh Iklim Sekolah Terhadap Mutu Lulusan}

Iklim sekolah yang terdiri dari indikator lingkungan belajar, lingkungan fisik, dan lingkungan sosial digunakan untuk mengukur kondisi lingkungan pada masing-masing sekolah pada SMA Negeri di Kota Semarang, Kabupaten Semarang, dan Kota Jawa Tengah.

Berdasarkan hasil pengujian, diperoleh hasil bahwa iklim sekolah berpengaruh secara langsung terhadap mutu lulusan secara positif dan signifikan sebesar $31,7 \%$, yang bermakna bahwa setiap peningkatan satu satuan iklim sekolah akan meningkatkan variabel mutu lulusan sebesar $31,7 \%$ dengan ketentuan variabel lain dalam penelitian ini tetap. Hal ini sesuai dengan penelitian terdahulu yang dilakukan oleh (Azhari, 2017) bahwa kontribusi iklim sekolah yang secara langsung mempengaruhi mutu sekolah.

\section{Pengaruh Mutu Proses Terhadap Mutu Lulusan}

Proses pembelajaran yang berlangsung di sekolah diduga akan menentukan kualitas baik tidaknya suatu mutu lulusan. Dalam penelitian ini indikator mutu proses terdiri dari perencanaan pembelajaran, pelaksanaaan pembelajaran, hubungan guru dengan siswa, dan evaluasi pembelajaran. Guru sebagai pemeran utama yang menentukan baik tidaknya suatu mutu proses di dalam sekolah.
Hasil pengujian yang dilakukan peneliti dalam penelitian ini menunjukkan bahwa terdapat pengaruh psoitif dan signifikan mutu proses terhadap mutu lulusan sebesar 31,3\%, yang bermakna bahwa setiap kenaikan satu satuan dalam mutu proses akan meningkatkan $31,3 \%$ dalam mutu lulusan dengan kondisi variabel lain daalam penelitian ini tetap. Hasil tersebut sesuai dengan penelitian terdahulu yang dilakukan oleh Riffandi, (2013) mutu pembelajaran berpengaruh secara positif dan signifikan terhadap kompetensi lulusan.

\section{Pengaruh Biaya Pendidikan Terhadap Mutu Proses}

Nanang Fatah (2001) menambahkan biaya dalam pendidikan meliputi biaya langsung (direct cost) dan biaya tidak langsung (indirect cost). Biaya langsung terdiri dari biaya-biaya yang dikeluarkan untuk keperluan pelaksanaan pengajaran dan kegiatan belajar siswa. Sedangkan biaya tidak langsung berupa keuntungan yang hilang (earning forgone) dalam bentuk biaya kesempatan yang hilang (opportunity cost) yang dikorbankan oleh siswa selama belajar.

Berdasarkan hasil pengujian, biaya pendidikan berpengaruh secara positif dan signifikan terhadap mutu proses sebesar 36,8\%, yang berarti bahwa setiap kenaikan biaya pendidikan satu satuan akan meningkatkan mutu proses sebesar $36,8 \%$, dan sisanya $63,2 \%$ dipengaruhi oleh variabel lain, dengan catatan variabel lain seperti kepemimpinan kepala sekolah, peran komite sekolah, dan iklim sekolah tetap. Hal ini sesuai dengan penelitian Fadillah dkk (2015) bahwa faktor utama penentu mutu pendidikan ialah berkaitan erat dengan biaya pendidikan.

\section{Pengaruh Kepemimpinan Kepala Sekolah Terhadap Mutu Proses}

Kepala sekolah sebagai pemegang otoritas tertinggi dalam sekolah memiliki kebijakan dalam mengatur proses pembelajaran yang berlangsung di dalam sekolah, sehingga diduga ada pengaruh psoitif dan signifikan kepemimpinan kepala sekolah etrhadap mutu proses. 
Kepemimpinan kepala sekolah sesuai dengan hasil pengujian yang dilakukan oleh peneliti menunjukkan hasil tidak ada pengaruh secara signifikan kepemimpinan kepala sekolah terhadap mutu lulusan, sebagaimana yang telah dijelaskan sebelumnya. Namun, sesuai dengan hail uji kepemimpinan kepala sekolah berpengaruh secara positif dan signifikan terhadap mutu proses sebesar $21 \%$, dan sisanya $79 \%$ dipengaruhi variabel lain. Hal tersebut berarti bahwa setiap peningkatan satu satuan dalam kepemimpinan kepala sekolah akan berpengaruh terhadap peningkatan mutu proses sebesar $21 \%$, dengan kondisi variable lain seperti biaya pendidikan, peran komite sekolah, dan iklim sekolah tetap. Hal ini sesuai dengan Herawan (2016) bahwa terdapat hubungan yang signifikan antara variable kepemimpinan kepala sekolah terhadap variabel peningkatan mutu pembelajaran.

\section{Pengaruh Peran Komite Sekolah Terhadap Mutu Proses}

Peran komite sekolah yang aktif, akan memberi dampak terhadap kegiatan proses pembelajaran yang berlangsung di sekolah. Beradasarkan hasil pengujian dalam penelitian ini, peran komite sekolah berpengaruh secara positif dna signifikan terhadap mutu proses pada SMA Negeri di Kota Semarang, Kabupaten Semarang, dna Kota Salatiga sebesar $14,7 \%$ dan sisanya $85,3 \%$ dipengaruhi variabel lain. Hal tersebut bermakna bahwa setiap kenaikan satu satuan dalam peran komite sekolah akan berdampak pada kenaikan mutui proses pada SMA Negeri di Kota Semarang, kabupaten Semarang, dan Kota Salatiga sebesar $14,7 \%$ dengan catatan yaitu biaya pendidikan, kepemimpinan kepala sekolah, dan iklim sekolah tetap.

\section{Pengaruh Iklim Sekolah Terhadap Mutu Proses}

Beradasarkan hasil pengujian iklim sekolah berpengaruh secara positif dan signifikan terhadap mutu proses sebesar $34.4 \%$, berariti bahwa setiap kenaikan iklim sekolah sebesar satu satuan akan meningkatkan mutu proses pada SMA Negeri di Kota Semarang,
Kabupaten Semarang, dna Kota Salatiga sebesar $34.4 \%$ dan sisanya dipengaruhi variabel lain sebesar $65,6 \%$, dengan kondisi varaibel lain yaitu biaya pendidikan, kepemimpina kepala sekolah, dan peran komite sekolah tetap. Hal ini sesuai dengan penelitian Dewi (2017) bahwa terdapat pengaruh positif dan signifikan iklim sekolah terhadap mutu pembelajaran

\section{Pengaruh Biaya Pendidikan Terhadap Mutu Lulusan melalui Mutu Proses}

Hasil pengujian dalam penelitian ini menunjukkan hasil bahwa terdapat pengaruh positif dan signifikan secara tidak langsung biaya pendidikan terhadap mutu lulusan dengan mutu proses sebagai variabel intervening pada SMA Negeri di Kota Semarang, Kabupaten Semarang dan Kota Salatiga sebesar $11,5 \%$, dan sisanya $88,5 \%$ dipengaruhi variabel lain. Hal tersebut berarti bahwa setiap peningkatan satu satuan biaya pendidikan melalui mutu proses akna mempengaruhi mutu lulusan sebesar 11,5\%, dengan kondisi variabel lain tetap.

Biaya pendidikan secara langsung maupun tidak langsung sama-sama memeiliki pengaruh etrhadap mutu lulusan pada SMA Negeri di Kota Semarang, Kabupaten Semarang dan Kota Salatiga. Besarnya pengaruh tidak langsung biaya pendidikan lebih rendah jika dibandingkan dengan besarnya pengaruh langsung biaya pendidikan terhadap mutu lulusan. Rendahnya pengaruh inimenunjukkan bentuk partial mediation dari mutu proses sebagai variabel intervening, yang artinya bahwa mutu proses tidak mampu memediasi secara sempurna pengaruh antara biaya pendidikan terhadap mutu lulusan.

\section{Pengaruh Kepemimpinan Kepala Sekolah Terhadap Mutu Lulusan melalui Mutu Proses}

Memahami sekolah sebagai suatu sistem penting karena konsep sekolah yang efektif tidak terlepas dan terpisahkan dengan pemahaman komprehensif mengenai sekolah sebagai suatu sistem (Komariah dan Triatna, 2010:1). Sekolah sebagai suatu sistem 
mencangkup di dalamnya yaitu komponen input. Dimana salah satu bagian dari input dalam sekolah yaitu kepemimpinan kepala sekolah.

Hasil pengujian dalam penelitian ini menunjukkan hasil bahwa tidak terdapat pengaruh positif dan signifikan secara tidak langsung kepemimpinan kepala sekolah terhadap mutu lulusan dengan mutu proses sebagai variabel intervening pada SMA Negeri di Kota Semarang, Kabupaten Semarang dan Kota Salatiga.

Kepemimpianan kepala sekolah secara langsung maupun tidak langsung sama-sama tidak memiliki pengaruh terhadap mutu lulusan pada SMA Negeri di Kota Semarang, Kabupaten Semarang dan Kota Salatiga. Hal ini bisa disebabkan karena perbedaan objek penelitian,waktu penelitian, lokasi penelitian, dan pengaruh lain yang tidak diteliti dalam penelitian ini.

\section{Pengaruh Peran Komite Sekolah Terhadap Mutu Lulusan melalui Mutu Proses}

Hasil pengujian dalam penelitian ini menunjukkan hasil bahwa tidak terdapat pengaruh positif dan signifikan secara tidak langsung peran komite sekolah terhadap mutu lulusan dengan mutu proses sebagai variabel intervening pada SMA Negeri di Kota Semarang, Kabupaten Semarang dan Kota Salatiga.

Peran komite sekolah jika dibandingkan secara langsung berpengaruh secara positif dan signifikan terhadap mutu lulusan sebesar 43,3\% dan secara tidak langsung tidak memiliki pengaruh terhadap mutu lulusan pada SMA Negeri di Kota Semarang, Kabupaten Semarang dan Kota Salatiga. Hal ini menunjukkan bahwa variabel mutu proses tidak berhasil memediasi peran komite sekolah terhadap mutu lulusan, bisa disebabkan karena perbedaan objek penelitian,waktu penelitian, lokasi penelitian, dan pengaruh lain yang tidak diteliti dalam penelitian ini.

\section{Pengaruh Iklim Sekolah Terhadap Mutu Lulusan melalui Mutu Proses}

Sesuai dengan teori General System yang menjelaskan bahwa suatu sistem tidak dipandang secara terpisah, tetapi saling terpadu satu sama lain, yang didalamnya terdiri dari berbagai komponen yang saling mendukung. Komponen tersebut mencangkup input, proses, dan output. Iklim sekolah merupakan bagian dari input sistem sekolah atau pendidikan.

Beradasrkan hasil pengujian dalam penelitian ini menunjukkan hasil bahwa terdapat pengaruh positif dan signifikan secara tidak langsung iklim sekolah terhadap mutu lulusan dengan mutu proses sebagai variabel intervening pada SMA Negeri di Kota Semarang, Kabupaten Semarang dan Kota Salatiga sebesar $10.8 \%$, dan sisanya $80,2 \%$ dipengaruhi variabel lain. Hal tersebut berarti bahwa setiap peningkatan satu satuan biaya pendidikan melalui mutu proses akna mempengaruhi mutu lulusan sebesar 10,8\%, dengan kondisi variabel lain tetap.

Iklim sekolah secara langsung maupun tidak langsung sama-sama memiliki pengaruh terhadap mutu lulusan pada SMA Negeri di Kota Semarang, Kabupaten Semarang dan Kota Salatiga. Besarnya pengaruh tidak langsung iklim sekolah lebih rendah jika dibandingkan dengan besarnya pengaruh langsung biaya pendidikan terhadap mutu lulusan. Rendahnya pengaruh ini menunjukkan bentuk partial mediation dari mutu proses sebagai variabel intervening, yang artinya bahwa mutu proses tidak mampu memediasi secara sempurna pengaruh antara iklim sekolah terhadap mutu lulusan.

\section{SIMPULAN}

Simpulan dalam penelitian ini yaitu: (1) Secara parsial biaya pendidikan, kepemimpinan kepala sekolah, komite sekolah, iklim sekolah, mutu proses berpengaruh positif dan signifikan terhadap mutu lulusan pada SMA Negeri di Kota Semarang, Kabupaten Semarang, dan Kota Salatiga. (2) Biaya pendidikan, kepemimpinan kepala sekolah, iklim sekolah secara parsial 
berpengaruh secara positif dan signifikan terhadap mutu proses pada SMA Negeri di Kota Semarang, Kabupaten Semarang, dan Kota Salatiga, (3) komite sekolah tidak berpengaruh secara positif dan signifikan terhadap mutu proses pada SMA Negeri di Kota Semarang, Kabupaten Semarang, dan Kota Salatiga. (4) biaya pendidikan berpengaruh secara positif dan signifikan terhadap mutu lulusan melalui mutu proses pada SMA Negeri di Kota Semarang, Kabupaten Semarang, dan Kota Salatiga, (5) kepemimpinan kepala sekolah tidak berpengaruh secara positif dan signifikan terhadap mutu lulusan melalui mutu proses pada SMA Negeri di Kota Semarang, Kabupaten Semarang, dan Kota Salatiga, (6) peran komite sekolah tidak berpengaruh secara positif dan signifikan terhadap mutu lulusan melalui mutu proses pada SMA Negeri di Kota Semarang, Kabupaten Semarang, dan Kota Salatiga, (7) iklim sekolah berpengaruh secara positif dan signifikan terhadap mutu lulusan melalui mutu proses pada SMA Negeri di Kota Semarang, Kabupaten Semarang, dan Kota Salatiga.

\section{DAFTAR PUSTAKA}

Alvionita, V. A. V., \& Armas, R. A. R. (2014) Pengaruh Pembiayaan Pendidikan dan Sarana Pembelajaran terhadap Prestasi Belajar Siswa pada Mata Pelajaran Ekonomi di SMA Negeri 11 Pekanbaru. Jurnal Online Mahasiswa Fakultas Keguruan dan Ilmu Pendidikan Universitas Riau, 2(1), 1-12.

Azhari, U. L., \& Kurniady, D. A. (2017). Manajemen Pembiayaan Pendidikan, Fasilitas Pembelajaran, Dan Mutu Sekolah. Jurnal Pendidikan, 23(2).

Dewi, P. F. (2018). Pengaruh Guru Profesional dan Iklim Sekolah Terhadap Mutu Pembelajaran SD Muhammadiyah Terpadu Ponorogo. Muslim Heritage, 2(2), 369-388.

Fadhilah, Umi Nur. (2015). Ini Tujuh Masalah Pendidikan di Indonesia Menurut JPPI. https://republika.co.id/berita/pendidikan/e duaction/17/05/03/opchjr354-ini-tujuhmasalah-pendidikan-di-indonesiamenurut-jppi (3 Juni 2018).

Fadillah, N., Agung, A., Agung, G., \& Yudana, I. M. (2015). Analisis Biaya Pendidikan Dan Hubungannya Dengan Mutu Pendidikan Pada SMPNegeri 2 Sukadasa Tahun Pelajaran 2013/2014. E-Journal Program Pascasarjana Universitas Pendidikan Ganesha Program Studi Administrasi Pendidikan. 6(1), 11. Bali: Universitas Pendidikan Ganesha.

Fattah, Nanang. (2001). Landasan Pendidikan. Bandung PT. Remaja Karya,

Hapsari, O., Hariyadi, S., \& Prihastuty, R. (2014). Pengaruh Iklim Sekolah Terhadap Kedisiplinan Belajar Siswa Kelas VII Di SMP Teuku Umar Semarang. Intuisi: Jurnal Psikologi Ilmiah, 6(1), 34-39.

Herawan, E. (2016). Kontribusi perilaku kepemimpinan transformasional kepala sekolah dan kinerja komite sekolah terhadap efektivitas implementasi manajemen berbasis sekolah. Jurnal Administrasi Pendidikan, 23(1), 40-48.

Jatengprov.go.id. (2018). Canangkan Semarang sebagai kota Literasi, di download Mei 2018

Komariah, Aan dan Cepi Triatna. (2010). Visionary Leadership Menuju Sekolah Efektif. Bandung: PT. Bumi Aksara.

Kompri. (2015). Manajemen Sekolah Orientasi Kemandirian Kepala Sekolah. Yogyakarta: Pustaka Pelajar.

Mulyono. (2010) Konsep Pembiayaan Pendidikan. Yogyakarta: Ar-Ruzz Mdia.

Ningsih, R. S., Herawan, E., \& Sutarsih, C. (2016). Kinerja Manajerial Kepala Sekolah, Iklim Sekolah dan Mutu Sekolah Dasar. Jurnal Administrasi Pendidikan, 23(2), 149-160.

Peraturan Pemerintah Republik Indonesia Nomor 19 Tahun 2017 tentang Perubahan atas Peraturan Pemerintah Nomor 74 Tahun 2008 tentang Guru. http://sipuu.setkab.go.id/PUUdoc/175233/ 
PP\%2019\%20Tahun\%202017.pdf (3 Mar. 2018)

Permendikbud Nomor 75 Tahun 2016. komite Sekolah

Permendiknas No. 28 Tahun 2010 tentang Penugasan Guru sebagai Kepala Sekolah,

Puspendik Kemendikbud. (2017). Profil Pendidikan Dasar dan Menengah Provinsi Jawa Tengah Tahun 2016/2017.

. (2018). laporan hasil ujian nasional, diunduh Feb 2018

Republik Indonesia. UU No. 20 Tahun 2003 tentang Sistem Pendidikan Nasional . UUD 1945

Riffandi, A. (2013) Mutu Pembelajaran dan Kompetensi Lulusan Diploma III Politeknik. Cakrawala Pendidikan, 1, 125138

Solihin, A. W. (2017). Kontribusi Kinerja Manajerial Kepala Dan Kinerja Komite Terhadap Mutu SD Negeri Di Kecamatan Jatiwangi. Jurnal Administrasi Pendidikan, 21(1), 42-48.

Suroto. (2017). Peran Komite Sekolah Dianggap Belum Maksimal Sebagai Penyalur Aspirasi Wali Murid, mei 2017https://www.solopos.com/perankomite-sekolah-dianggap-belummaksimal-sebagai-penyalur-aspirasi-walimurid-817360

Triyono, Agus. (2016). Efektifivitas anggaran pendidikan masih gagal. https://nasional.kontan.co.id/news/efektifivi tas-anggaran-pendidikan-masih-gagal Juni 2018) 